\title{
Impacts of sea-level rise-induced erosion on the Catalan coast
}

José A. Jiménez ${ }^{1 *}$, Herminia I. Valdemoro ${ }^{1}$, Eva Bosom ${ }^{1}$, Agustín Sánchez-Arcilla ${ }^{1}$, Robert J. Nicholls $^{2}$

${ }^{1}$ Laboratori d'Enginyeria Marítima, Universitat Politècnica de Catalunya $\cdot$ BarcelonaTech, c/Jordi Girona 1-3, Campus Nord ed D1, 08034 Barcelona, Spain.

${ }^{2}$ Faculty of Engineering and the Environment, University of Southampton, Southampton SO17 1BJ, UK

e-mails: jose.jimenez@upc.edu, herminia.valdemoro@upc.edu, ebosom@gmail.com, agustin.arcilla@upc.edu,r.j.nicholls@soton.ac.uk

* Corresponding author (phone: +34 934016469) jose.jimenez@upc.edu

\begin{abstract}
The Catalan coast as most of the developed Mediterranean coastal zone is characterized by the coincidence of stresses and pressures on the natural system with a high exposure and low adaptive capacity. Due to this, Climate Change-induced effects will increase natural hazards and aggravate their associated impacts and, in consequence, it is necessary to assess their effects for proper long-term management. In this work, we assess the impact of sea-level rise (SLR) induced shoreline retreat on the Catalan coast for three scenarios ranging from $0.53 \mathrm{~m}$ to $1.75 \mathrm{~m}$ by the year 2100 . Implications are analyzed in terms of affectation of two main functions provided by beaches, i.e. recreation and protection. Obtained results show that CC will be a serious threat to analyzed functions since the expected enhanced shoreline retreat will severely decrease the recreational carrying capacity and, the capacity of protection in the near future under tested scenarios. The actual level of development along the coastal zone reduces the natural resilient capacity of beaches to SLR in such a way that, the lack of accommodation space can be identified as a main factor for the estimated impacts.
\end{abstract}

Keywords: climate change, erosion, vulnerability, tourism, protection, coastal management

Length of the paper: $5,666+6$ fig +1 table (eq to 2,100 words) total: 7,766 words

\section{Introduction}


Coastal zones are some of the most productive areas on Earth, attracting and concentrating human population. From an anthropocentric standpoint, they provide land for housing and infrastructure development; goods and services for developing human (economic) activities and ecosystem services providing tangible and intangible benefits for human development (UNEP, 2006). Accordingly, one of the main characteristics of this area is its high susceptibility to change/damage due to the accumulation of human-induced pressures (e.g. Steffen et al. 2007; Newton et al. 2012). Thus, Newton et al. (2012) identified a number of impacts associated with coastal utilization and development such as erosion, reduced freshwater flow, habitats destruction and urban development. Within this context, coastal hotspots can be defined as regions largely affected by the combined presence of natural hazards and human vulnerability. The Mediterranean Sea represents a good example of such a regional hotspot comprising numerous locations where these impacts are concentrated (UNEP 2009).

In addition, it is likely that climate change (CC) induced hazards will increase the forcing on coastal hotspots and, as a direct consequence, will intensify their impacts on the coastal system, becoming a major additional driver of changes in coastal land use (Hadley, 2009). Hence, coastal management needs to consider these new conditions to properly minimize the associated impacts, and to optimize the use of the coastal zone while protecting natural values. The interest in assessing potential implications of climate change on the Mediterranean coasts has driven numerous research at different scales and approaches such as at the basin level (e.g. Nicholls and Hoozemans, 1996; Jeftic et al. 1996), at the regional scale (e.g. Snoussi et al. 2008; Torresan et al. 2012; Sierra et al. 2016), at local scale (e.g. SánchezArcilla et al. 2011) and at the geomorphic unit scale (e.g. Sánchez-Arcilla et al 2008; ElNahry and Doluschitz 2010). 
Among the different climate change drivers, storminess and sea level rise (SLR) are the most relevant from the coastal hazard perspective since they should originate and/or intensify the most important ones, i.e. erosion and inundation. Regarding storminess, most of existing projections of surge and wave height in the Mediterranean have found that they are not likely to increase during the 21st century (Lionello et al., 2008; Conte and Lionello, 2013). However, the uncertainty about projections of extreme wave events is relatively large since the use of different atmospheric models can result in different wave fields (Planton et al. 2012). This variation in wave projections was also detected by Casas-Prat and Sierra (2013) in the study area by using different combinations of Regional and Global Circulation Models.

Due to this, in this work we just focus on the potential impacts of SLR on coastal hazards. SLR impacts on coastal zones are well known (e.g. Nicholls and Cazenave 2010) with inundation and accelerated erosion being the two most important ones affecting coastal stability.

Inundation is usually considered as an immediate hazard in which coastal areas at an altitude lower than the new (rise) water level and hydraulically connected to the shoreline will be subjected to submergence. In most of the cases, its assessment implicitly assumes no coastal adjustment to the new mean water level. In sedimentary coasts, and at the long-term perspective, shoreline should adjust to new conditions in such a way that, in the absence of any compensatory mechanism, a rise in the mean sea level will result in the retreat of unprotected coastlines (e.g. Nicholls and Cazenave 2010). In spite of this, most of the existing impact studies focus on inundation (e.g. Titus and Richman 2001; Li et al. 2009), with few cases specifically dealing with induced erosion (e.g. Hinkel et al. 2013). Due to this and taking into account the importance of sedimentary coasts for the socio-economic development of the Mediterranean countries in general and, Spain in particular, this work focusses on the evaluation of the SLR-induced erosion effects. 
Thus, the main aim of this work is to assess the impact of sea-level rise induced shoreline retreat on a Mediterranean coastal hotspot. This will permit to assess how ongoing processes and hazards are accelerated or aggravated as well as to assess their implications for future coastal management. This will be done at a regional scale by analysing the case of the Catalan coast which is used as an example of the Mediterranean developed coasts.

From the perspective of management, it is specially important to assess how a given climate forcing propagates through the coastal system via direct and indirect impacts. In this sense, Figure 1 shows a representation of the impact chain for SLR-induced erosion in the Catalan coast, where the main expected impacts are identified.

Since the objective of the analysis is to contribute to coastal management through hazard and impact assessment, this study has focused on SLR scenarios covering the range provided by the IPCC AR5 (Church et al. 2013) as well as one high-end scenario. This last scenario has been selected from the high risk-management perspective which as Hinkel et al (2015) clearly pointed out can be tackled by defining an upper bound such as a worst-case scenario.

\section{Study area and Methods}

\subsection{Study area}

The Catalan coast is located in the NE Spanish Mediterranean (Figure 2). It has about $600 \mathrm{~km}$ long coastline, with about $270 \mathrm{~km}$ of beaches. It has a wide variety of temperate coastal systems comprising considerable geo- and biodiversity which is represented in cliffs, rocky coasts, sandy beaches, coastal plains, estuaries, and river deltas. 
Figure 2 shows the study area divided into 12 administrative units (comarcas) that concentrate in just $22.8 \%$ of the surface, the $61.9 \%$ of the population of Catalonia $(4.68$ million people in 2013, IDESCAT 2014) and the $64.9 \%$ of the Catalan Gross Domestic Product (GDP). Current socioeconomic activities reflects the typical conditions of Mediterranean coastal areas and are based on activities such as tourism, commerce, agriculture, and, until recent dates, residential developments (e.g. Sardá et al 2005). The spatial distribution of main socioeconomic (GDP, population and tourist accommodation offer) and environmental (surface of protected areas of natural interest) indicators along the coast is shown in Fig 2 (see further details in Brenner et al (2006).

The hotspot condition of the Catalan coast arises from the combination of natural and societal factors and, it corresponds to situations in which pressures on the natural system coincide with a high exposure and low adaptive capacity:

- Most of its population is concentrated in the coastal zone. The average population density in coastal municipalities is 1,518 people $/ \mathrm{km}^{2}$, whereas the mean value for Catalonia is 232 people $/ \mathrm{km}^{2}$.

- Tourism is one of the main economic activities providing $11.1 \%$ of the Catalan GDP (Duro and Rodriguez, 2011). Coastal tourism is the major contributor with coastal destinies comprising $62,9 \%$ of tourism overnights.

- Coastal ecosystem services when translated into economic values represent a quantifiable and substantial contribution to wellbeing of coastal communities. In market price terms, they provide the equivalent of each family receiving an additional $4.3 \%$ in available income every year (Brenner et al 2010).

- It contains 4 important low-lying areas with the Ebro delta being the largest one.

- It is an eroding coast with about $70 \%$ of beaches retreating during the last decades at a mean rate of about $-0.7 \mathrm{~m} /$ year (CIIRC 2010). 
- Coastal damage has significantly increased during the last 50 years in spite of the absence of an increasing trend in storm-induced hazards (Jiménez et al 2012).

\subsection{Shoreline retreat}

It is widely accepted that in the absence of any compensatory mechanism, a rise in the mean sea level will result in the retreat of unprotected coastlines (Nicholls and Cazenave, 2010). Although the total coastal response at the local scale will depend on the total sediment budget (e.g. Stive 2004; Cowell et al. 2006), the most common way to assess SLR-induced coastal retreat is the so-called Bruun rule (e.g. Le Cozannet et al. 2014). Bruun (1962) suggests that under a scenario of rising sea levels, the beach profile will respond by maintaining constant its relative position and shape with respect to the new mean sea level.

Recent reviews about the validity of this model suggest that it can be suitable for qualitative regional scale assessments, but not recommended for local scale assessments where high quantitative accuracy be required except in the case of absence of littoral transport gradients and presence of sediment sources/sinks (e.g. Stive et al 2009). Cooper and Pilkey (2004) concluded that the assumptions to be satisfied for applying this model are very restrictive and, in consequence it should only likely to be applicable on a small number of coasts. Ranasinghe et al (2012) proposed a probabilistic model based on governing physical processes to estimate coastal erosion (PCR) due to SLR. However, these authors explicitly stated that "several simplifying assumptions in the model need to be rigorously evaluated" and some elements of the model need to be defined using empirical evidence that are often absent (e.g. coast recovery processes).

In the absence of a general accepted morphological model, we assume that the order of magnitude of regional-scale SLR-induced response on sedimentary coasts can be estimated 
using the Bruun model. The model predicts a landwards and upwards movement of the profile, which results in a shoreline retreat, $\Delta X$, given by

$$
\Delta \mathrm{X}=\Delta \mathrm{MWL} \frac{\mathrm{L}}{\left(\mathrm{B}+\mathrm{d}_{*}\right)} \approx \Delta \mathrm{MWL} / \mathrm{S}_{\mathrm{act}}
$$

where $\triangle M W L$ is the sea level rise, $B$ is the berm/dune height of the active beach, $d *$ is the active or closure depth (maximum depth where significant profile changes are observed), $L$ is the across-shore distance from $B$ to $d *$ and $S_{a c t}$ is the averaged inner shelf slope where beach profile changes. To reduce the uncertainty in the selection of the closure depth in the study area (see discussion in Ranasinghe and Stive, 2009), instead of selecting a specific depth, we have used characteristic values of the inner shelf slope, calculated from the shoreline to $10 \mathrm{~m}$ depth for different locations along the Catalan coast.

Retreat and beach rebuilding due to SLR will only be possible if accommodation space is available: is there sufficient hinterland behind the shoreline where the beach could migrate. If not, the beach will be eroded and will progressively decline and ultimately disappear. One of the problems of the Catalan coast, as with most of the Mediterranean coastline, is that it is heavily urbanized and, in consequence, most of beaches are backed by fixed infrastructures such as promenades and transport links or other rigid boundaries limiting the accommodation space.

It has to be stressed that the required accommodation space is a relative concept. It is related to the expected magnitude of the shoreline retreat, and it can be defined as the required space to permit the rebuilding of a given beach width at a given time horizon under a given shoreline rate of displacement. 
The effect of the existing accommodation space is locally assessed by taking into account the expected shoreline retreat under a given SLR scenario and the actual beach width (distance from the shoreline to existing barrier in the hinterland). When the accommodation space is smaller than the expected shoreline retreat at a given time, the beach will disappear.

\subsection{Impact on beach functions}

To calculate the impact of the decrease in available beach width resulting from enhanced erosion to beach functions, we define here the called optimum and failure beach states. The optimum state is given by beach width equal or larger than the required one to properly provide the considered function whereas the failure state corresponds to a beach significantly narrower than the required one. Once these two limits are defined for each function, beaches are classified in three categories according to their projected width at a given time horizon: optimum, medium and low (see table 1).

For recreation, the optimum beach width has been selected in the range $35 \mathrm{~m}-40 \mathrm{~m}$ which is a representative value for Spanish Mediterranean beaches (Valdemoro and Jiménez 2006). This value corresponds to the usual size of the resting and active zones occupied by beachgoers. Low quality beaches are given by a configuration that, under a given tourist flow, results in an excessive users' density (see table 1).

For protection, the optimum beach has to be wide enough to dissipate the energy supplied by a storm of a given return period, $T r$, (Bosom and Jiménez, 2011; Jiménez et al 2011). The $\operatorname{Tr}$ value to be considered depends on the importance of values at exposure to be protected. Taking into account the characteristics of the Catalan coast we have defined

optimum beaches as those wider than the expected cumulative storm-induced erosion associated to return periods of 50 and 25 years. Low quality beaches are those narrower than 
the storm-induced erosion associated to a relatively frequent event ( $T r=25$ years). Values associated with these probabilities are site-specific because they depend on local wave and beach characteristics. In this work, we have obtained a representative regional value by averaging storm-induced erosion climates obtained for different areas along the Catalan coast (see Table 1).

\subsection{Sea-level rise}

Present sea level trends in the Mediterranean basin have been estimated by Marcos and Tsimplis (2008) by analysing available tide-gauge records longer than 35 years, although as these authors stressed, existing data are biased towards the North coast. They calculated for the longest records in the Mediterranean a sea level trend between $1.2 \mathrm{~mm} \mathrm{yr}^{-1}$ and $1.5 \mathrm{~mm} \mathrm{yr}^{-}$ ${ }^{1}$. The only station where a larger trend was observed was Venice with a rate of $2.5 \mathrm{~mm} \mathrm{yr}^{-1}$ which was influenced by subsidence. Gomis et al (2012) reported that mean sea level in the Mediterranean has been rising at a rate of $0.6 \pm 0.1 \mathrm{~mm} \mathrm{yr}^{-1}$ during the period 1948-2000, which is much lower than global mean sea level during the period 1971-2010 (between 1.7 and $2.3 \mathrm{~mm} \mathrm{yr}^{-1}$, Church et al. 2013).

Regarding the Catalan coast, there is no sea level time series long enough to make a reliable analysis. In spite of this, Marcos and Tsimplis (2008) analysed a sea level 13 years long time series in the Barcelona Harbour and obtained a sea level trend of $1.7 \pm 1.5 \mathrm{~mm} \mathrm{yr}^{-1}$. To illustrate the potential variability of sea level changes in the basin, these authors estimated for locations northwards (Marseille) and southwards (Alicante) of the study area a trend of $1.2 \pm 0.1$ $\mathrm{mm} \mathrm{yr}^{-1}$ and $-0.3 \pm 0.2 \mathrm{~mm} \mathrm{yr}^{-1}$ respectively. 
In spite of the before mentioned uncertainties, it should be useful and necessary for future planning of Mediterranean coasts to have a first estimation of the expected range of impacts induced by climatic-driven SLR. Taking into account that the main objective is to help in the process of coastal risk management, this study considers SLR scenarios covering the range provided by the IPCC AR5 and one extreme scenario. These are given by the best guess (50\% probability) scenarios for RCP4.5 and RCP8.5 from AR5 (Church et al. 2013) and by a high-end scenario (see Figure 3). This last scenario was taken from the ones generated by Jevrejeva et al. (2014) and it is given by the projection of sea level at $95 \%$ probability of the Upper limit scenario using the RCP8.5 steric component (see Jevrejeva et al. 2014 for details). They are given by the year 2100 relative to 2000 by $0.53 \mathrm{~m}, 0.74 \mathrm{~m}$ and $1.75 \mathrm{~m}$ respectively.

In addition to these values, local contributions to SLR such as subsidence need to be also considered. With respect to this, areas with the largest susceptibility to subsidence along the Catalan coast are formed by the recent sediment deposits in deltas and low-lying areas (Copons, 2008). Unfortunately, there is a lack of systematic measurements of subsidence rates along the Catalan coast with most existing values corresponding to inferred Quaternary subsidence rates (e.g. Liquete et al. 2008; Vacchi et al. 2016). For the most important area subjected to subsidence, the Ebro delta, reported values differ since they have been obtained by different means, many times without accuracy enough to properly bound their associated uncertainty (Alvarado-Aguilar et al. 2012). Reported values go from $1.75 \mathrm{~mm} \mathrm{yr}^{-1}$ (Somoza et al. 1998) during the Holocene up to larger values derived for current conditions with a representative average subsidence rate of $3 \mathrm{~mm} \mathrm{yr}^{-1}$ (Ibañez et al. 1997; Jiménez et al. 1997). For the Llobregat delta plain, Duro et al (2004) reported average present-day values of $1.25 \mathrm{~mm} \mathrm{yr}^{-1}$ reaching a maximum of $6 \mathrm{~mm} \mathrm{yr}^{-1}$ in the presence of soft sediment rich in pore 
water and organic matter (see also Liquete et al 2008). Gamez et al (2009) characterized the Llobregat delta continental shelf as highly subsidence area (see also Vacchi et al 2016).

\section{Results}

\subsection{Shoreline retreat}

SLR-induced coastline retreat will only affect geomorphic active (sedimentary) shorelines, with passive or rocky coasts being unable to respond to such forcing. Thus, about $52 \%$ of the Catalonian coastline will not be affected by SLR-induced erosion because it is composed by rocky and cliff (43\%) and human built (9\%) environments. The distribution of the passive coastline is directly controlled by the existing geomorphology along the Catalan coastal zone, with the largest percentage (67\%) being located at the Northernmost area (Costa Brava), a highly indented coast dominated by cliffs and bay and pocket beaches. The composition of the passive (rigid) part of the Catalan coast is clearly dominated (about $83 \%$ ) by the natural component (cliff and rocky coasts), with the exception of Maresme (coast northwards of Barcelona) where the rigid coastline is essentially human-built (revetment protecting the coastal railway and other coastal protection structures).

Calculated retreats along the $21^{\text {st }}$ century for the different sectors of the Catalan sedimentary coast under each SLR scenario are shown in Figure 3. They are bounded by values obtained in two areas which significantly depart from the average behaviour. On the one hand, the Ebro delta behaves as an erosional hotspot because, due to its very mild shoreface slope, SLR-induced shoreline retreat is between 2 and 3 times the obtained for the rest of the coast. Moreover, this site is also affected by subsidence which will increase the 
expected erosion. On the other hand, the Tordera delta behaves as the less sensitive area due to its very steep slope in such a way that expected shoreline retreat will be very low. Since this behaviour is essentially controlled by the shoreface morphology, it is reproduced for all tested SLR scenarios.

For RCP scenarios, the average SLR-induced shoreline retreat for the most representative part of the Catalan coast (excluding the two previously mentioned sectors) is almost equal at 2050 ( $20 \mathrm{~m}$ and $22 \mathrm{~m}$ for RCP4.5 and RCP8.5 respectively). However, due to the acceleration in SLR predicted for RCP8.5, the difference between expected shoreline retreats significantly increases at 2100 (47 m and $65 \mathrm{~m}$ for RCP4.5 and RCP8.5 respectively).

Calculated shoreline retreats under the high-end scenario are about 2 times higher than those associated to RCP scenarios at 2050, increasing up to 3 times at 2100. Averaged values (excluding the two extreme sectors) are $41 \mathrm{~m}$ and $153 \mathrm{~m}$ at 2050 and 2100 respectively.

Applying Equation (1), the additional shoreline retreats induced by subsidence at 2100 are $14 \mathrm{~m}$ and $63 \mathrm{~m}$ for the Llobregat delta and Ebro delta, respectively. These values should be added to the estimates shown in Fig 3 to obtain the total shoreline retreat for 2100 due to relative sea level rise (RSLR).

At present, only the $24 \%$ of the Catalan coastal is backed by a hinterland providing some accommodation space to permit the dynamic adaptation of beaches to SLR. Figure 4 shows the length of existing beaches along the Catalan coast under tested SLR scenarios with and without accounting for the existence of available space for beach accommodation. For relatively low SLR scenarios and/or short time horizons the relevance of the existence of accommodation space is relatively low. Under these conditions, the induced shoreline retreat is low and, only narrow and very narrow beaches should be fully eroded due to SLR. Since beaches backed by a hinterland providing accommodation space are usually wide (they are in pristine or low developed environments), its effective contribution to beach survival under 
low retreats will be low. For high SLR scenarios and long-time horizons (2100), the current existing accommodation space along the coast significantly increases the beach survival. Thus, the beach survival at 2100 , measured in terms of the length of existing beaches, increases in $93 \mathrm{~km}, 57 \mathrm{~km}$ and $39 \mathrm{~km}$ for the High-end, RCP8.5 and RCP4.5 scenarios respectively.

In any case, it has to be stressed that we are accounting for the role of the current available accommodation space which has declined during the last decades due to the increase in urban development along the Catalan coastal zone. Without this human induced effect, the sedimentary coastline should be able to naturally adapt to this climate change induced hazard.

The presented survival rates have been calculated by comparing beach widths at present with the SLR-induced retreat calculated for given time horizons. They can be considered as optimistic estimations because they represent existing beaches wide enough to permit the expected shoreline retreat under the different CC scenarios. Since, the dominant behaviour of Catalan beaches during the last decades is erosive with an average shoreline retreat rate of about $0.7 \mathrm{~m} \mathrm{yr}^{-1}$ (CIIRC, 2010), it is expected that the role of the accommodation space will be much more important and relevant at shorter time horizons.

\subsection{Impacts on coastal functions}

To assess the expected impact of SLR-induced erosion and, in consequence, management implications, we have to estimate how $\mathrm{CC}$ is conditioning the functions being provided by the coast (see Fig 1). In what follows, these management implications are discussed for the Catalan coast grouped in two main values: recreation and protection.

\subsubsection{Recreation}


One of the potential impacts of climate change on coastal areas is the change in tourism demand due to the high relevance of climatic factors (e.g. Hamilton et al. 2005; Amelung and Viner 2006). Recently, Bujosa and Roselló (2013) analysed the effects of climate change (increase in temperature) on the behaviour of Spanish domestic coastal tourism. They found that although it was not possible to confirm a decrease in tourism on the Spanish Mediterranean coast under the tested climate scenarios, new competitors will emerge on the Northern Spanish coast, which could change the actual distribution of domestic coastal summer trips. However, Moreno and Amelung (2009) have concluded that although nonMediterranean coasts will likely benefit from climate change, the expected impacts of climate change on Mediterranean beach tourist comfort may be less severe than anticipated. In fact, they recommended to put attention on other climate change induced impacts such as sea-level rise and/or water availability as the key factors potentially affecting beach tourism.

With respect to the climate-induced hazard analysed here, the decrease in available beach width resulting from enhanced erosion is of most concern for beach recreation. Under a steady tourist flow, the decrease in available beach surface will produce an increase in users' density and, thus, a decrease in comfortability. When this process extends in time, users' density will approach the saturation level where the beach should eventually collapse from the recreational standpoint and visitors would migrate to an alternative destiny supplying required conditions.

Figure 5 shows the percentage of beaches classified in terms of their suitability to support recreational use for different time horizons and SLR scenarios. At 2050, just considering the SLR-induced shoreline retreat, the length of optimum beaches will decline from a present value of about $65 \%$ to about $45 \%$ for the RCP 4.5 and RCP 8.5 scenarios. At this time, differences between both scenarios are not significant due to the time evolution of 
SLR. During the first half of the century they are quite similar whereas SLR under RCP8.5 significantly increases with respect to RCP4.5 during the second half (see Figure 3). Under the High-end scenario, only about $25 \%$ of the sedimentary coast will be wide enough to provide optimum conditions for recreation. On the other hand, the coastal length with low recreational capacity beaches will significantly increase from around $12 \%$ in present conditions. To properly estimate this decrease in the recreational capacity we jointly consider very narrow beaches and those that will be fully eroded. The percentage of beaches falling in these two groups ranges from about $34 \%$ under the RCP4.5 and RCP8.5 scenarios to $61 \%$ under the High-end one. Observed differences between different scenarios are mainly reflected in the \% of disappearing beaches.

When the analysis is extended to 2100 , a dramatic decrease of the capacity of beaches to provide optimum recreational capacity is observed (Figure 5). Thus, only between $22 \%$ and $12 \%$ of the sedimentary coast will fall in this category under RCP4.5 and RCP8.5 scenarios respectively. Under the High-end scenario, nearly all beaches falling in optimum and medium recreational capacity conditions will disappear.

Previous figures have been calculated by assuming non-accommodation space conditions and, they should represent the worst scenario in terms of expected impact. In fact, most of Catalan beaches supporting an intense recreational use are characterized by the presence of infrastructures at their back (e.g. Valdemoro and Jiménez, 2006).

In spite of this, if we do the analysis taking into account the effect of the available accommodation space along the coast, the distribution of beaches in terms of their recreational capacity will change (Figure 5). Thus, main observed effects are the decrease in the percentage of beaches that will disappear and, the increase in the abundance of optimum beaches due to the beach rebuilding by wave action in the available space in the hinterland as shoreline retreats. As it is expected, these effects will be more important as larger the induced 
shoreline retreat will be, i.e. under high SLR rates and long-time horizons (Figure 5). Although these results indicate a larger resilience of beaches to SLR, it has to be considered that areas with accommodation space are usually not important from the recreational use standpoint (at present) since they are generally located in natural areas.

\subsubsection{Protection}

As it was previously mentioned, protection refers to the function provided by the beach to protect the hinterland from wave action during storms and, it is supported by dissipating the energy supplied by a storm of a given return period.

As no increase in storminess has been considered, the decrease in available beach width resulting from climate change-induced enhanced erosion should be the most impacting potential harm affecting the protection function. Figure 6 shows the percentage of beaches falling in each category of protection capacity to storm-induced erosion for different time horizons and SLR scenarios. The pattern of variation is similar to that obtained for recreation since width intervals to classify beaches are of similar magnitude (see table 1). Under current conditions, about the $7.5 \%$ of the total beach length along the Catalan coast fall into the low protection capacity, with about the $75 \%$ presenting optimum conditions. At 2050 , the effect of SLR-induced shoreline retreat declines the length of optimum capacity beaches to about $55 \%$ and 50\% under the RCP4.5 and RCP8.5 scenarios respectively. Under the High-end scenario, only the $29 \%$ of the sedimentary coast will be wide enough to provide optimum conditions for protection.

At 2100 the expected coastline length with an optimum beach configuration to provide enough protection to the hinterland are about $22 \%$ and $12 \%$ under the RCP4.5 and RCP 8.5 scenarios respectively and, only the $0.14 \%$ under the High-end scenario. The situation 
regarding protection will be critical at this time horizon since the percentage of coast with fully eroded beaches and, in consequence, with a full exposure of the hinterland, will be about 47\%, 68\% and 99\% for RCP4.5, RCP8.5 and High-end scenarios respectively.

As in the case of recreation, when the effects of the existence of accommodation space are accounted for, a decrease in the percentage of beaches failing to provide protection (low category and fully eroded decreases), especially for High-end scenario and long time horizons. In spite of this, areas with accommodation space do not usually have significant values at exposure nor infrastructures and, in consequence, the apparent increase in the protection provided at regional scale it is not very relevant since these areas are mostly nondeveloped coastal environments.

\section{Discussion and Conclusions}

This study has focussed on sea-level rise scenarios up to $1.75 \mathrm{~m}$ by 2100 which are consistent with the range defined by the IPCC AR5 report plus one extreme High-end scenario. It should be acknowledged that large rises in SLR could occur and it is prudent to consider these when assessing impacts and adaptation (Nicholls et al., 2013; Hinkel et al. 2015). Obtained results show that climate change induced effects such as SLR will significantly affect coastal hotspots as Catalonia by increasing the magnitude of natural hazards and/or by decreasing the capacity to cope with them. In this sense, it has to be considered that the final coastal response to RSLR will strongly depend on the overall sediment budget. Thus, sediment supplies to the coast are very important for both horizontal and vertical accretion, which potentially act as resilient processes to erosion and inundation hazards, respectively. Following global trends of decreasing continental sediment supplies to the coastal zone (Syvitski et al 2005), rivers along the Catalan coast are playing a decreasing 
role in contributing to coastal stability due to the significant human influence in their drainage basins. As an example, the most important river discharging in the Spanish Mediterranean coast, the Ebro river, has experienced a significant decreasing trend in annual water discharge $\left(-221 \mathrm{hm}^{3} /\right.$ year) since the 60 's. This coincides with a significant increase in the number of active dams and barriers in its drainage basin (173 active dams/barrages at present) in such a way that about $96 \%$ of the drainage basin is fully regulated. The rest of rivers discharging along the Catalan coast are also affected in a different degree by human activities such as damming, water extraction, urbanization and sand and gravel mining (Liquete et al. 2009). Due to this, we can conclude that the present and future role of river sediment inputs to counteract SLR-induced erosion is nearly negligible.

Under this scenario of SLR-induced retreat, the following potential changes are expected. Climate change will be a serious threat to coastal tourism in Catalonia as the expected enhanced shoreline retreat will severely decrease the recreational beach carrying capacity in the near future under tested scenarios. This will have a serious impact on the economy due to the importance of this sector for the Catalan GDP. To sustain the recreational use under the expected range of SLR adequate adaptation measures must be taken to compensate erosion which, in most of the cases, will involve the replacement of the sediment volume being eroded. This can be accompanied by using the resilient behaviour in areas with accommodation space. However, this will imply to promote a shift of the recreational use from current urbanized locations to more natural areas where beaches have no internal barriers.

Similarly, the protection function provided by Catalan beaches will also be affected by climate change. Here, the target objective should be to maintain the level of protection of infrastructures along the hinterland under $\mathrm{CC}$. The induced shoreline retreat will severely 
decrease the capacity of protection and, in consequence, an increase in coastal damage will occur without any change in storminess.

Since the main identified problem for recreation and protection is a loss of beach width, adaptation measures should be directed to how most effectively to maintain these widths. Since the required resources (sediment and money) are not unbounded, any effective policy should include a robust criteria to select areas where it is most effective and beneficial concentrate efforts. In any case, both approaches (large scale nourishment and managed retreat) imply a much more strategic approach to beach management than is currently the case on the Catalan coast.

The Catalan coast has been used as a paradigm of coastal hotspots in the Mediterranean basin because stresses and pressures on the natural system coincide with a high exposure and low adaptive capacity. Under a future affected by Climate Change in general, and SLR in particular, this hotspot condition will be exacerbated due to an increase in natural hazards unless a determined and timely societal response is taken.

\section{Acknowledgements}

This work has been done in the framework of the PaiRisClima and RISES-AM and RISCKIT research projects funded by the Spanish Ministry of Economy and Competitiveness (CGL201455387-R) and the European Commission (Grants No. 603396 and No 603458) respectively.

\section{References}


Alvarado-Aguilar D, Jiménez JA, Nicholls RJ (2012) Flood hazard and damage assessment in the Ebro Delta (NW Mediterranean) to relative sea level rise. Nat Hazards 62: 13011321. doi: 10.1007/s11069-012-0149-x

Amelung B, Viner D (2006) Mediterranean tourism: Exploring the future with the Tourism Climate Index. J Sustain Tour 14: 349-366. doi: 10.2167/jost549.0

Bosom E, Jiménez JA (2011) Probabilistic coastal vulnerability assessment to storms at regional scale - application to Catalan beaches (NW Mediterranean). Nat Hazard Earth Sys 11: 475-484. doi:10.5194/nhess-11-475-2011

Brenner J, Jiménez JA, Sardá R (2006) Definition of Homogeneous Environmental Management Units for the Catalan Coast. Environ Manage 38: 993-1005. doi: $10.1007 / \mathrm{s} 00267-005-0210-6$

Brenner J, Jiménez JA, Sardá R, Garola A (2010) Non market value of the ecosystem services provided by the Catalan coast, Spain. Ocean Coast Manage 53: 27-38. doi: 10.1016/j.ocecoaman.2009.10.008

Bruun P (1962) Sea level rise as a cause of shore erosion. J Waterw Harbour Div 88: 117-130

Bujosa A, Roselló J (2013) Climate change and summer mass tourism: the case of Spanish domestic tourism. Climatic Change 117: 363-375. doi: 10.1007/s10584-012-0554-X

Casas-Prat M, Sierra JP (2013) Projected future wave climate in the NW Mediterranean Sea. J Geophys Res Oceans 118.7: 3548-3568. doi: 10.1002/jgrc.20233

Church JA, Clark PU, Cazenave A, Gregory JM, Jevrejeva S, Levermann A, Merrifield MA, Milne GA, Nerem RS, Nunn PD, Payne AJ, Pfeffer WT, Stammer D, Unnikrishnan AS. (2013). Sea Level Change. In: Stocker TF, Qin D, Plattner G-K, Tignor M, Allen SK, Boschung J, Nauels A, Xia Y, Bex V, Midgley PM (eds.). Climate Change 2013: The Physical Science Basis. Contribution of Working Group I to the Fifth Assessment Report 
of the Intergovernmental Panel on Climate Change. Cambridge University Press, Cambridge, pp. 1137-1216

CIIRC (2010) Estat de la zona costanera a Catalunya. Resum Executiu. Generalitat de Catalunya, Barcelona

Conte D, Lionello P (2013) Characteristics of large positive and negative surges in the Mediterranean Sea and their attenuation in future climate scenarios. Global Planet Change 111: 159-173. doi: 10.1016/j.gloplacha.2013.09.006

Cooper JAG, Pilkey OH (2004) Sea-level rise and shoreline retreat: time to abandon the Bruun Rule. Global Planet Change 43: 157-171. doi: 10.1016/j.gloplacha.2004.07.001 Copons R (2008) El risc d'esfondraments i subsidències a Catalunya. RISKCAT 2008, Consell Assessor per al Desenvolupament Sostenible, Generalitat de Catalunya

Cowell PJ, Thom BG, Jones RA, Everts CH, Simanovic D (2006) Management of uncertainty in predicting climate-change impacts on beaches. J Coast Res 22: 232-245. doi: $10.2112 / 05 \mathrm{~A}-0018.1$

Duro JA, Rodríguez D (2011) Estimació del PIB turístic per Catalunya, marques i comarques 2005-2010. Report GRIT, Universitat Rovira i Virgili, Tarragona

Duro J, Inglada J, Closa J. Adam N, Arnaud A (2004) High resolution differential interferometry using time series of ERS and Envisat SAR Data. Proc. of FRINGE 2003 Workshop, ESA SP-550

El-Nahry AH, Doluschitz R (2010) Climate change and its impacts on the coastal zone of the Nile Delta, Egypt. Environ Earth Sci 59: 1497-1506. doi: 10.1007/s12665-009-0135-0

Gámez D, Simó JA, Lobo FJ, Barnolas A, Carrera J, Vázquez-Suñé E (2009) Onshoreoffshore correlation of the Llobregat deltaic system, Spain: Development of deltaic geometries under different relative sea-level and growth fault influences, Sedimen Geol 217: 65-84. doi: 10.1016/j.sedgeo.2009.03.007. 
Gomis D, Tsimplis M, Marcos M, Fenoglio-Marc L, Pérez B, Raicich F, Vilibić I, Wöppelmann G, Monserrat S (2012) Mediterranean Sea Level Variability and trends. In: Lionello P (Ed) The Climate of the Mediterranean Region. Elsevier, London, pp 257-299. doi: 10.1016/B978-0-12-416042-2.00004-5

Hadley D (2009) Land use and the coastal zone. Land Use Pol 26S: S198-S203. doi: 10.1016/j.landusepol.2009.09.014

Hamilton JM, Maddison DJ, Tol RSJ (2005) The effects of climate change on international tourism. Clim Res 29: 245-254

Hinkel J, Nicholls RJ, Tol RS, Wang ZB, Hamilton JM, Boot G, Vafeidis AT, McFadden L, Ganopolski A, Klein RJ (2013). A Global Analysis of Coastal Erosion of Beaches due to Sea-level Rise: An Application of DIVA. Global Planet Change 111: 150158. doi: 10.1016/j.gloplacha.2013.09.002

Hinkel J, Jaeger C, Nicholls RJ, Lowe J, Renn O, Peijun S, (2015) Sea-level rise scenarios and coastal risk management. Nat Clim Change 5: 188-190. doi:10.1038/nclimate2505

Ibáñez C, Canicio A, Day JW, Curcó A (1997) Morphologic development, relative sea level rise and sustainable management of water and sediment in the Ebre Delta, Spain. J Coast Conserv 3:191-202. doi: 10.1007/BF02905244

IDESCAT. 2014. Anuari Estadístic de Catalunya. www.idescat.cat (accessed 28/06/14)

Jeftic L, Keckes S, Pernetta JC (1996) Climate change and the Mediterranean and societal impacts of climatic change and sea level rise in the Mediterranean region. Edward Arnold, London

Jevrejeva S, Grinsted A, Moore JC (2014) Upper limit for sea level projections by 2100. Environ Res Lett 9: 104008. doi: 10.1088/1748-9326/9/10/104008

Jiménez JA, Sánchez-Arcilla A, Valdemoro HI, Gracia V, Nieto F (1997) Processes reshaping the Ebro delta. Mar Geol 144: 59-79. doi: 10.1016/S0025-3227(97)00076-5 
Jiménez JA, Gracia V, Valdemoro HI, Mendoza ET, Sánchez-Arcilla A (2011) Managing erosion-induced problems in NW Mediterranean urban beaches. Ocean Coast Manage 54: 907-918. doi: 10.1016/j.ocecoaman.2011.05.003

Jiménez JA, Sancho A, Bosom E, Valdemoro HI, Guillén J (2012) Storm-induced damages along the Catalan coast (NW Mediterranean) during the period 19582008. Geomorphology 143-144: 24-33. doi: 10.1016/j.geomorph.2011.07.034

Le Cozannet G, Garcin M, Yates M, Idier D, Meyssignac B (2014) Approaches to evaluate the recent impacts of sea-level rise on shoreline changes. Earth Sci Rev, 138: 47-60. doi:10.1016/j.earscirev.2014.08.005

Li XG, Rowley RJ, Kostelnick JC, Braaten D, Meisel J, Hulbutta K (2009) GIS analysis of global impacts from sea level rise. Photogramm Eng Rem S 75: 807-818. doi: 10.14358/PERS.75.7.807

Lionello P, Cogo S, Galati MB, Sanna A. (2008) The Mediterranean surface wave climate inferred from future scenario simulations. Global Planet Change 63: 152-162. doi: 10.1016/j.gloplacha.2008.03.004

Liquete C, Canals M, De Mol B, De Batist M, Trincardi F (2008) Quaternary stratal architecture of the Barcelona prodeltaic continental shelf (NW Mediterranean). Mar Geol 250: 234-250. doi: 10.1016/j.margeo.2008.01.014

Liquete C, Canals M, Ludwig W, Arnau P (2009) Sediment discharge of the rivers of Catalonia, NE Spain, and the influence of human impacts. J Hydrol 366: 76-88. doi: 10.1016/j.jhydrol.2008.12.013

Marcos M, Tsimplis MN (2008) Coastal sea level trends in Southern Europe. Geophys J Int 175: 70-82. doiI: 10.1111/j.1365-246X.2008.03892.x

Moreno A, Amelung B (2009) Climate change and tourist comfort on Europe's beaches in summer: a reassessment. Coast Manag 37: 550-568. doi: 10.1080/ 08920750903054997 
Newton A, Carruthers TJB, Icely J (2012) The coastal syndromes and hotspots on the coast. Estuar Coast Shelf S 96: 39- 47. doi: 10.1016/j.ecss.2011.07.012

Nicholls RJ, Cazenave A (2010) Sea-level rise and its impact on coastal zones. Science 328: 1517-1520. doi: 10.1126/science. 1185782

Nicholls RJ, Hanson SE, Lowe JA, Warrick RA, Lu X, Long AJ (2013) Sea-level scenarios for evaluating coastal impacts. WIREs Climate Change 2013, doi: 10.1002/wcc.253

Nicholls RJ, Hoozemans FMJ (1996) The Mediterranean: vulnerability to coastal implications of climate change. Ocean Coast Manage 31: 105-132

Planton S, Lionello P, Artale V, Aznar R, Carillo A, Colin J, Congedi L, Dubois C, Elizalde A, Gualdi S, Hertig E, Jacobeit J, Jordà Sanchez G, Li L, Mariotti A, Piani C, Ruti P, Sanchez-Gomez E, Sannino G, Sevault F, Somot S (2012) The Climate of the Mediterranean Region in Future Climate Projections. In: Lionello P et al. (eds) (2012) The climate of the Mediterranean region: from the past to the future. Elsevier, pp 449502. doi:10.1016/B978-0-12-416042-2.00008-2

Ranasinghe R, Stive MJF (2009) Rising seas and retreating coastlines. Climatic Change 97: 465-468. doi:10.1007/s10584-009-9593-3

Ranasinghe R, Callaghan D, Stive MJF (2012) Estimating coastal recession due to sea level rise: beyond the Bruun rule. Climatic Change 110: 561-574. doi: 10.1007/s10584-011$0107-8$

Reed DJ (1995) The response of coastal marshes to sea-level rise: Survival or submergence? Earth Surf Proc Land 20: 39-48. doi: 10.1002/esp.3290200105

Sánchez-Arcilla A, Jiménez JA, Valdemoro HI (1998) The Ebro delta: morphodynamics and vulnerability. J Coast Res 14: 754-772

Sánchez-Arcilla A, Jiménez JA, Valdemoro HI, Gracia V (2008) Implications of climatic change on Spanish Mediterranean low-lying coasts. The Ebro delta case. J Coast Res 24: 
306-316. doi: 10.2112/07A-0005

Sánchez-Arcilla A, Mösso C, Sierra JP, Mestres M, Harzallah A, Senouci M, El Raey M, ElAskary H (2011) Climatic drivers of potential hazards in Mediterranean coasts. Reg Environ Change 11: 617-636. doi: 10.1007/s10113-010-0193-6

Sardá R, Avila C, Mora J (2005) A methodological approach to be used in integrated coastal zone management process: the case of the Catalan Coast (Catalonia, Spain). Estuar Coast Shelf S 62:427-439. doi: 10.1016/j.ecss.2004.09.028

Sierra JP, Casanovas I, Mösso C, Mestres M, Sánchez-Arcilla A (2016) Vulnerability of Catalan (NW Mediterranean) ports to wave overtopping due to different scenarios of sea level rise. Reg Environ Change 16: 1457-1468. doi:10.1007/s10113-015-0879-x

Snoussi M, Ouchani T,Niazi S. 2008. Vulnerability assessment of the impact of sea-level rise and flooding on the Moroccan coast: The case of the Mediterranean eastern zone. Estuar Coast Shelf S 77: 206-213. doi: 10.1016/j.ecss.2007.09.024

Somoza L, Barnolas A, Arasa A, Maestro A, Rees JG, Hernández-Molina FJ (1988) Architectural stacking patterns of the Ebro delta controlled by Holocene high-frequency eustatic fluctuations, delta-lobe switching and subsidence processes. Sediment Geol 117: 11-32. doi: 10.1016/S0037-0738(97)00121-8

Steffen, W, Crutzen PJ, McNeill JR (2007) The anthropocene: are humans now overwhelming the great forces of nature? Ambio 36: 614-621. doi: 10.1579/00447447(2007)36[614:TAAHNO]2.0.CO;2

Stive MJF (2004) How important is global warming for coastal erosion? Climatic Change 64: 27-39. doi: 10.1023/B:CLIM.0000024785.91858.1d

Stive MJF, Ranasinghe R, Cowell P (2009) Sea level rise and coastal erosion. In: Kim Y (ed) Handbook of coastal and ocean engineering. World Scientific, pp 1023-1038 
Syvitski JPM, Vörösmarty CJ, Kettner AJ, Green P (2005) Impact of humans on the flux of terrestrial sediment to the global coastal ocean. Science 308: 376-380. doi: 10.1126/science. 1109454

Titus JG, Richman C (2001) Maps of lands vulnerable to sea level rise: modeled elevations along the US Atlantic and Gulf coasts. Clim Res 18: 205-228. Doi: 10.3354/cr018205

Torresan S, Critto A, Rizzi J, Marcomini A (2012) Assessment of coastal vulnerability to climate change hazards at the regional scale: the case study of the North Adriatic Sea. Nat Hazrds Earth Syst 12: 2347-2368. doi:10.5194/nhess-12-2347-2012

UNEP (2006) Marine and coastal ecosystems and human wellbeing: a synthesis report based on the findings of the millenium ecosystem assessment. UNEP-WCMC, Cambridge

UNEP (2009) State of the Environment and Development in the Mediterranean. UNEP/MAPPlan Bleu, Athens

Vacchi M, Marriner N, Morhange C, Spada G, Fontana A, Rovere A (2016) Multiproxy assessment of Holocene relative sea-level changes in the western Mediterranean: Sealevel variability and improvements in the definition of the isostatic signal. Earth-Sci Rev 155: 172-197. doi: 10.1016/j.earscirev.2016.02.002

Valdemoro HI, Jiménez JA (2006) The Influence of Shoreline Dynamics on the Use and Exploitation of Mediterranean Tourist Beaches. Coast Manage 34: 405-423. doi. $10.1080 / 08920750600860324$ 


\section{FIGURE LEGENDS}

Figure 1. Impact chain for sea-level rise induced erosion in the Catalan coast.

Figure 2. Area of study.

Figure 3. SLR scenarios used in this work and induced shoreline retreats for different parts of the Catalan coast (see location in Figure 1) under each scenario. Shadow areas represent the range of SLR-induced retreat for each scenario).

Figure 4. Total length of existing beaches along the Catalan coast under each SLR scenarios including and excluding the effects of the availability of accommodation space. Vertical bars at the right of the graph indicates the increase in beach survival (measured in $\mathrm{km}$ ) for each scenario at 2100.

Figure 5. Extension of beaches along the Catalan coast classified in terms of their configuration to support recreational use under each SLR scenario (eroded: \% of beaches fully eroded).

Figure 6. Extension of beaches along the Catalan coast classified in terms of their configuration to provide protection to the hinterland use under each SLR scenario (eroded: \% of beaches fully eroded). 


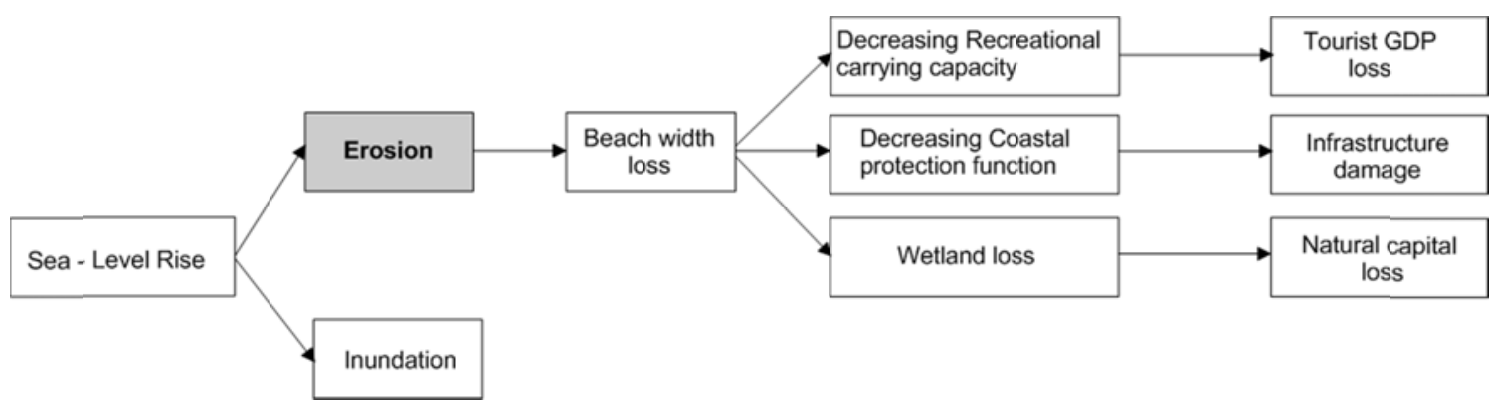

Figure 1. Impact chain for sea-level rise induced erosion in the Catalan coast. 


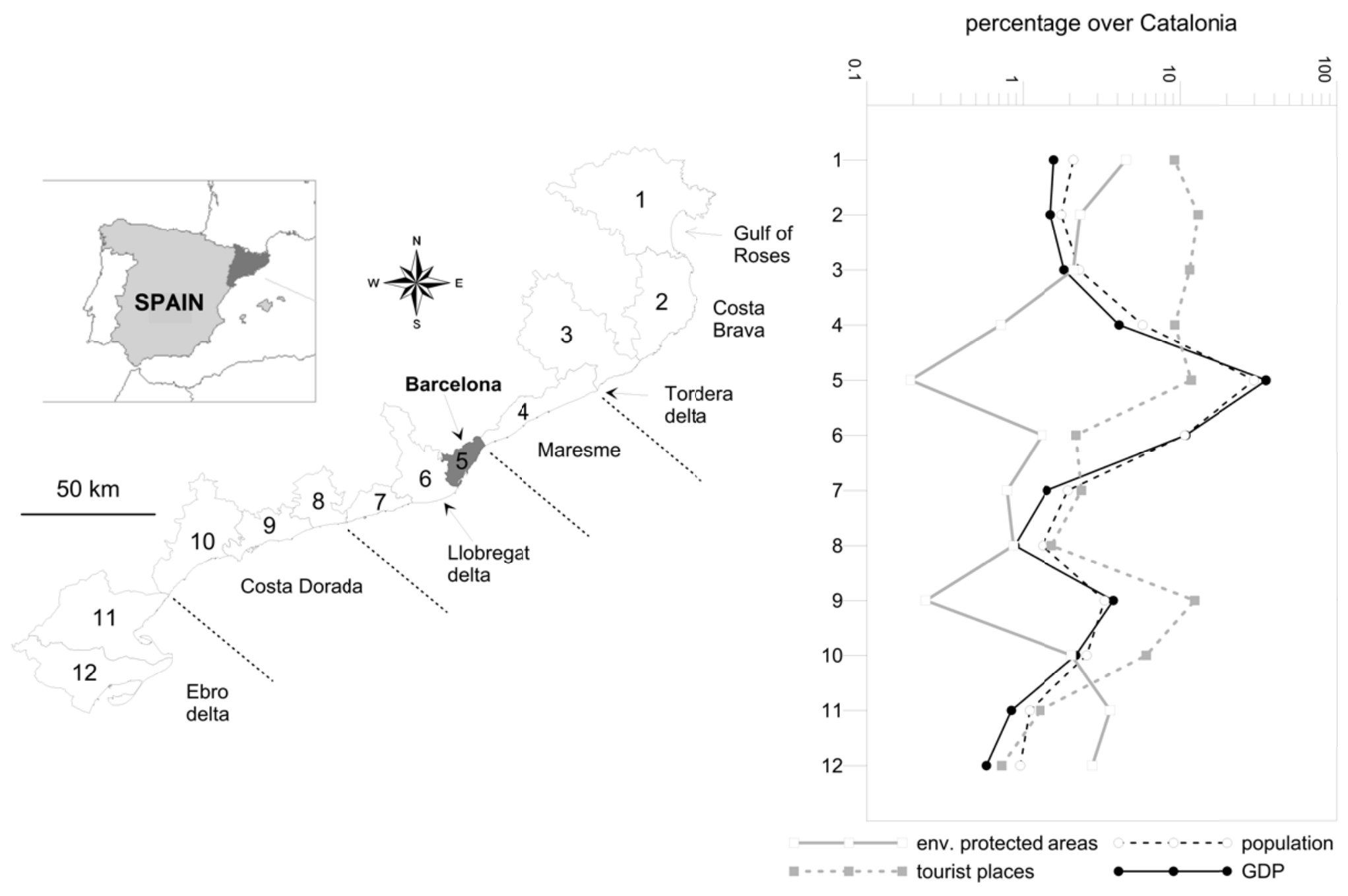

Figure 2. Area of study (numbers at the right figure refers to coastal comarcas). 

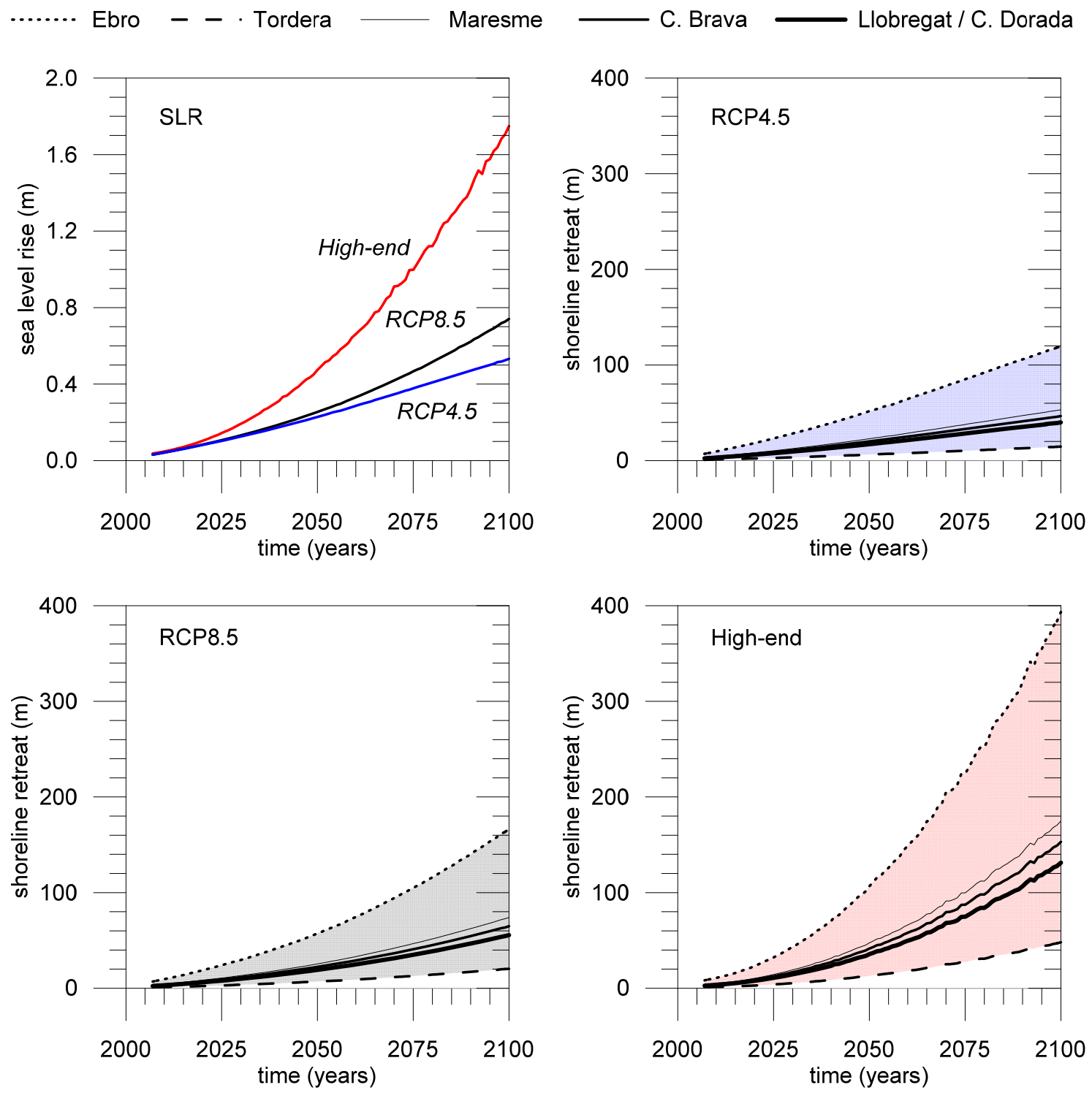

Figure 3. SLR scenarios used in this work and induced shoreline retreats for different parts of the Catalan coast (see location in Figure 1) under each scenario. Shadow areas represent the range of SLR induced retreat for each scenario). 


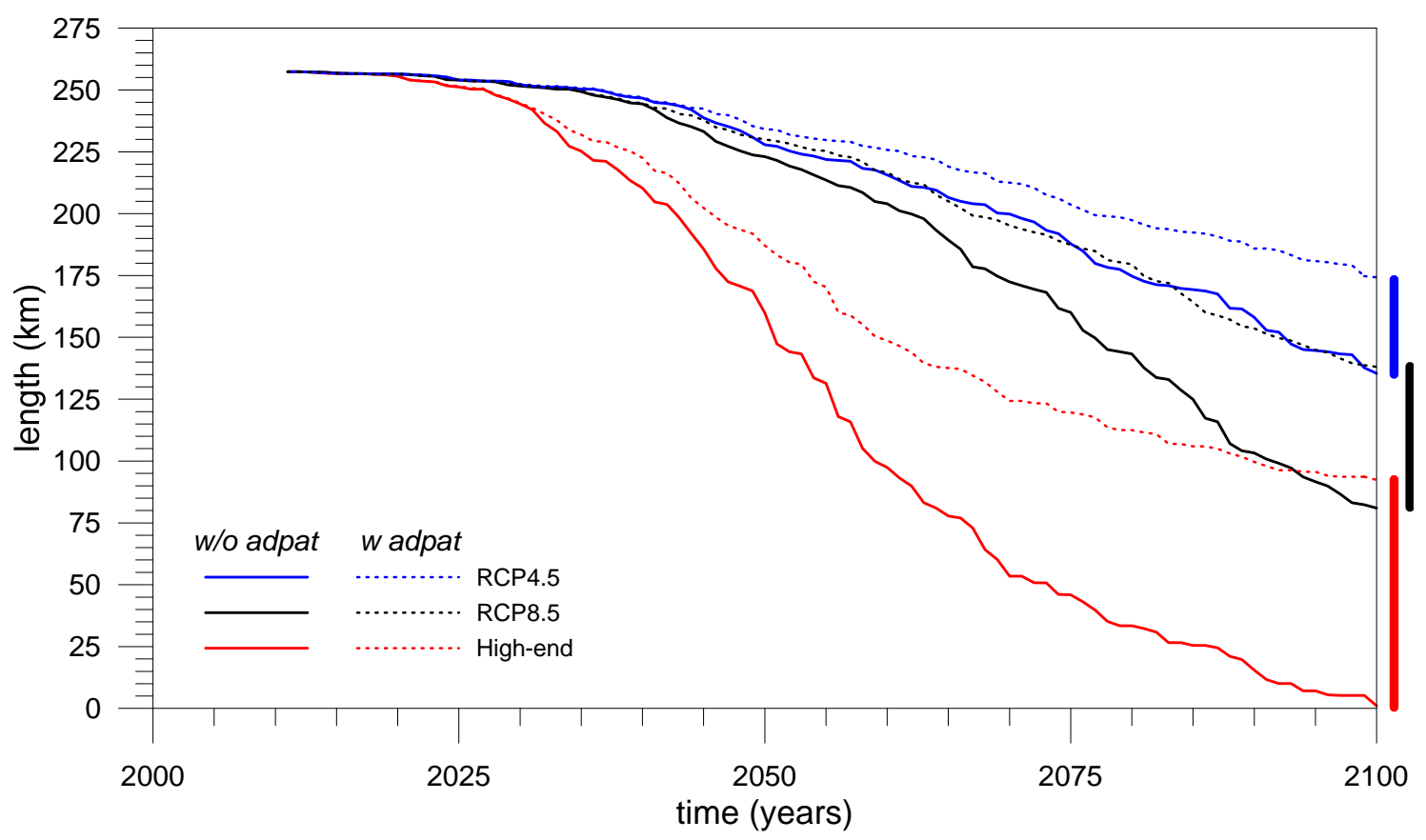

Figure 4. Total length of existing beaches along the Catalan coast under each SLR scenarios including and excluding the effects of the availability of accommodation space. Vertical bars at the right of the graph indicates the increase in beach survival (measured in $\mathrm{km}$ ) for each scenario at 2100. 


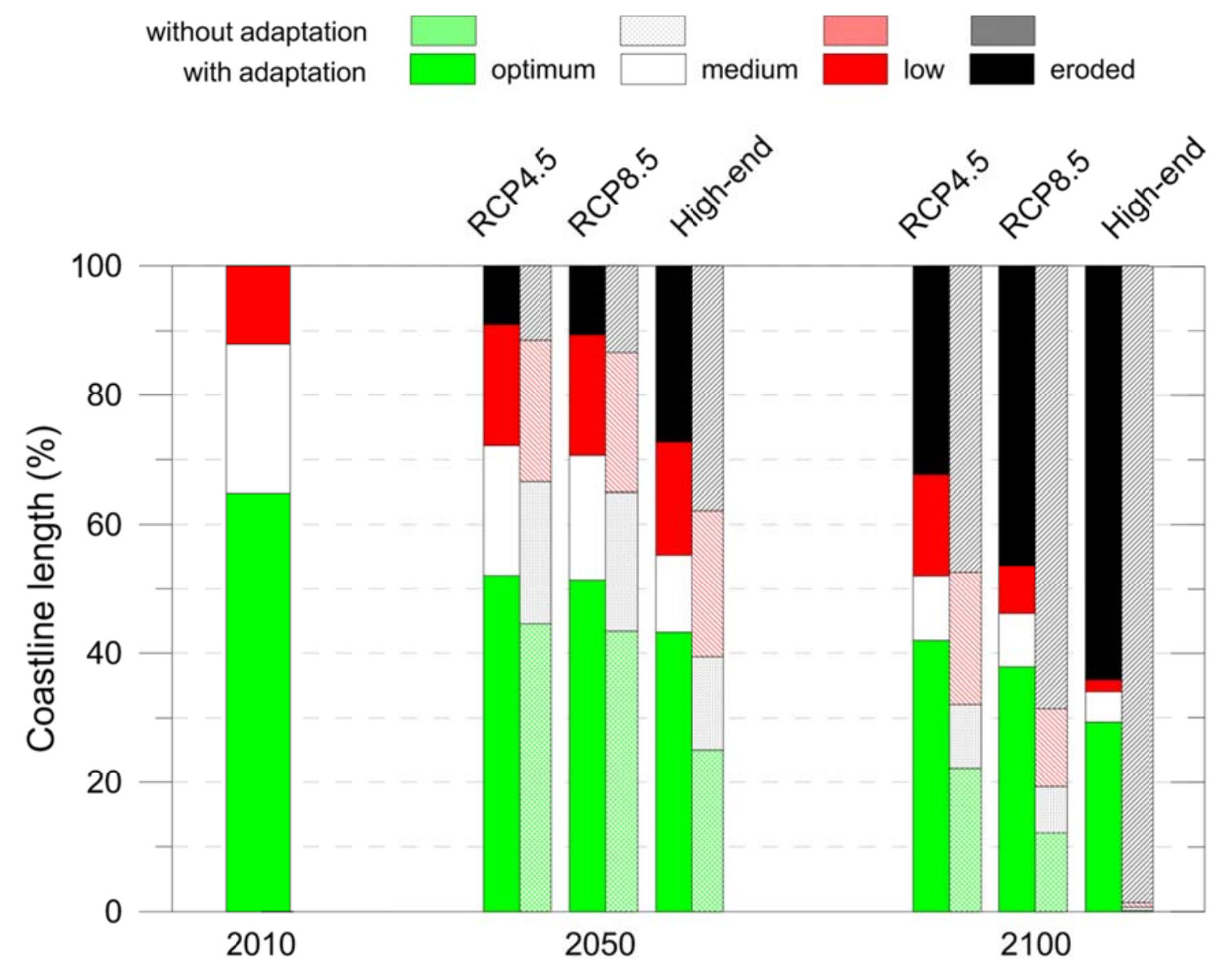

Figure 5. Extension of beaches along the Catalan coast classified in terms of their configuration to support recreational use under each SLR scenario (eroded: \% of beaches fully eroded). 


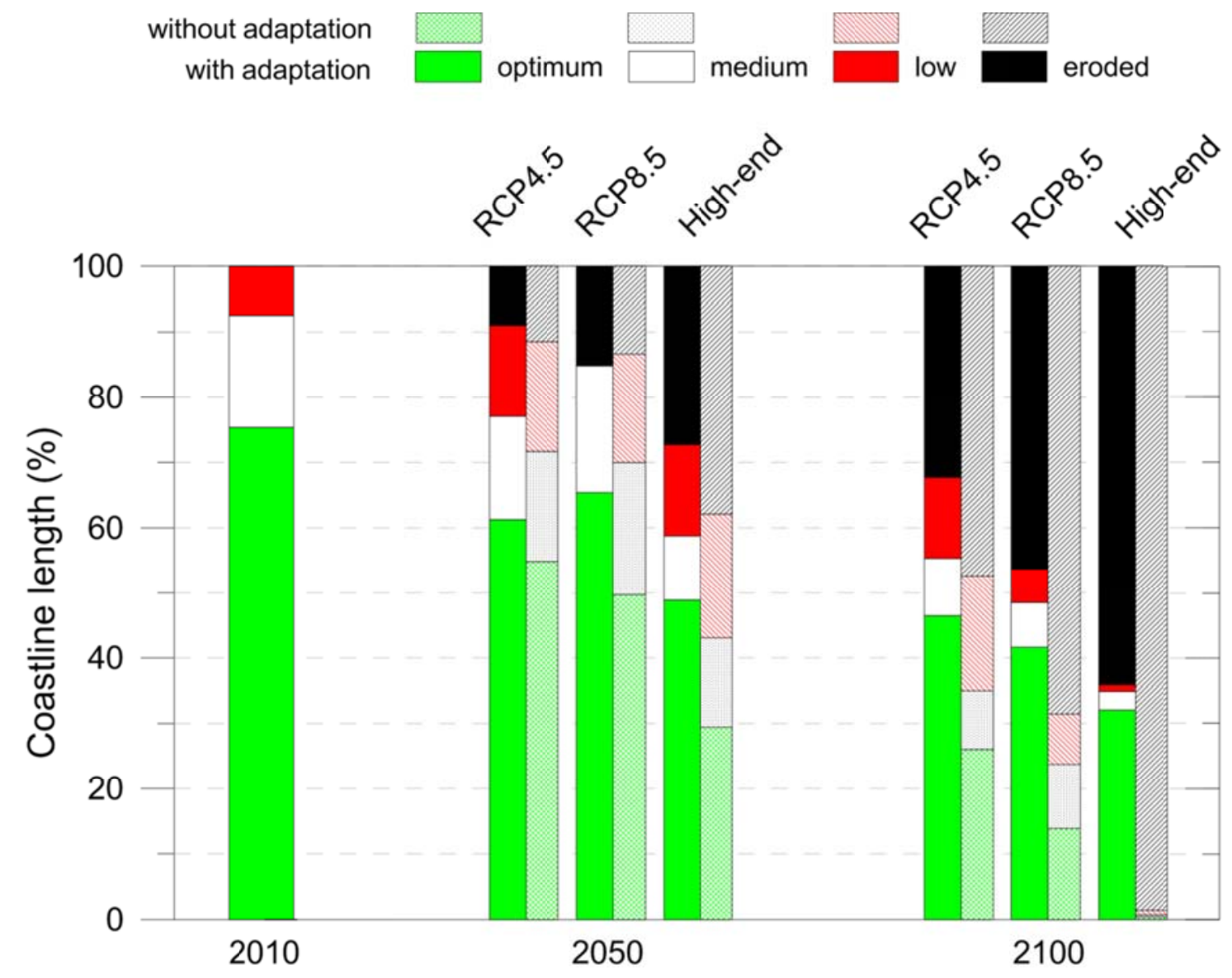

Figure 6. Extension of beaches along the Catalan coast classified in terms of their configuration to provide protection to the hinterland use under each SLR scenario (eroded: \% of beaches fully eroded). 
Recreation Protection

\begin{tabular}{lll}
\hline Optimum & $>40 \mathrm{~m}$ & $>32 \mathrm{~m}$ \\
Medium & $20 \mathrm{~m}-40 \mathrm{~m}$ & $15 \mathrm{~m}-32 \mathrm{~m}$ \\
Low & $<20 \mathrm{~m}$ & $<15 \mathrm{~m}$ \\
\hline
\end{tabular}

Table 1. Classification of beaches in terms of their width according to the provision of a given function. 